\title{
The Mediating Effect of Organizational Commitment on Leadership Type and Job Performance
}

\author{
Li Lin, Wang Shiqian \\ Department of Postgraduate Center, Limkokwing University of Creative Technology, Cyberjaya, Malaysia \\ Email address: \\ blue08122@gmail.com (Li Lin),wang.cngs@gmail.com (Wang Shiqian) \\ To cite this article: \\ Li Lin, Wang Shiqian. The Mediating Effect of Organizational Commitment on Leadership Type and Job Performance. Journal of World \\ Economic Research. Vol. 7, No. 1, 2018, pp. 14-20. doi: 10.11648/j.jwer.20180701.12
}

Received: December 19, 2017; Accepted: January 20, 2018; Published: February 27, 2018

\begin{abstract}
In order to active the education industry and make a contribution for the higher education field, private higher education becomes a backbone force in Chinese society. Based on the report of Ministry of Education in 2017 mentioned that the biggest problem with private higher education is that the weak and unstable academic staffs which lead to low job performance. In addition to policies and management, how to further improve the quality and performance of academicians is also an essential issue eager to be solved in private education institutions. Therefore, how to construct qualified personnel is one of the fundamental problems in the survival and development of private colleges and universities. The performance and quality of the academic staffs largely determines the quality of private colleges and universities. Leadership style was regarded as an importance role affect organizational commitment and organizational performance. This study intends to find out the mediating effect of organizational commitment on the relationship between leadership style and job performance by using the survey data from academicians of top ten Chinese private universities.
\end{abstract}

Keywords: Leadership Type, Organizational Commitment, Job Performance, Mediating Effect

\section{Introduction}

According to Noordin and Jusoff [1], societal expectations depend upon the successful running of the education process and policy. The success of the education system depends on the assiduous and contribution of academicians. Hence, academicians' job performance becomes an essential element for every educational institution. Higher complacent of the academicians results in impressive performance and thus healthy and positive climate of the institute will exists [1]. Chinese private higher education has experienced both unprecedented rapid growth and significant fluctuations in the last three decades, and is now facing serious challenges to its further development, so that they are eagerly to get development, with the key is how to improve the academicians' job performance [2]. Academicians play a major role to achieve the objectives of the university and a good academician has to teach effectively in the class in order to improve student's academic performance. Academicians' performance roughly includes research performance, teaching performance, consultancy, and contributions to society and administrative work apart from other factors such as employer reputation and proportion of international students.

\section{Literature Review}

\section{Leadership Style}

Leadership is defined as an effort to influence followers through the communication process to achieve certain goals. According to Robbins, (2001) leadership is the ability to influence a group of members to work toward organizational goals and objectives [3]. Ayes, A., (2012) clarifies that "leadership is regarded as the ability to influence and inspire ways of thinking, acting, and behaving of its members" [4]. Barbuto, J. E.ec. al., (2002) pointed out one of the available leadership style is transformational leadership, which defined as "a process of interaction between leaders and followers to pursue the higher level of morality and motivation" [5]. Bass, (1981) also pointed out that leadership style mainly comprise three common conditions, namely transformational leadership style, transactional leadership style and laissezfaire leadership style or condition without leadership [6]. Barbuto et. al., (2002) declared via a hundred years 
assessment, the emergence of transformational leadership style and transactional leadership style is the result, which are able to represent many kinds of leadership styles available all this time [5]. Conceptually, transformational leadership style is defined [6] [7] as the ability of leaders to change the work environment, work motivation, and work patterns, and work values perceived by subordinates so that they are better able to optimize performance to achieve organizational goals. While transactional leadership style is one leadership style that basically emphasizes agreement between leaders and subordinates. Transactional leadership allows leaders to motivate and influence subordinates by exchanging rewards with certain performance. That is, in a transaction, a subordinate were promised to be given appropriate compensation when subordinates are able to complete their duties in accordance with the contract [8]. The reason for this push Bass and [7] to define transactional leadership as a form of relationship that exchange office or a specific task if the subordinate is able to complete the task properly. Thus, transactional leadership emphasizes the exchange of valuable relationships to biological and psychological needs in accordance with the collaborative agreements they had signed.

Organizational Commitment

Robbins, (2001) defined organizational commitment is as "a state in which the employee identifies with a particular organization and its goals, and wishes to maintain membership in the organization [3]. Newstrom, J., \& Davis, K. (2007) identified organizational commitment means employee loyalty [9]. Schmuck, P., \& Schultz, W. P. (2002) said that it is displayed the employees' acceptance of organizational values and goals and willing to devote his loyalty to the organization, and it reflected by his continual desire to retain in the organization [10]. According to [11], organizational commitment is defined in multiple ways, organizational commitment refers to the employee's emotional attachment to, identification with, and involvement in organization, further it is generally considered as three dimensions comprising affective commitment, continuance commitment and normative commitment. Muchinsky, P. M. (2003) stated that the concept of organizational commitment shows the degree of an employee's sense of loyalty to organization [8]. Werner, A. (2007) indicated that organizational commitment refers to an employee who is engaged to the organization means that they are emotionally, cognitively and personally committed to the organization and willing to work exceeding the basic requirements and expectations of the job [12].

High organizational commitment is needed in organizations, since a high commitment will affect professional work atmosphere. According to [13], organizational commitment reflects the relative strength of an individual's identification with and involvement in organization. Garg, A. K, D. Ramjee, D. (2013) described organizational commitment is a psychological bond that is based on three forms, regarding to Three-Component Model of Organizational Commitment, comprise affective commitment, normative commitment, and continuance commitment [14].

According to [15] organizational commitment can be classified into three components. First, employees want to do work with strong affective commitment (recognition and attachment to the organization) to work continuously. Second, employees need to do work whom expect to remain in the organization based on continuance commitment (aware of the costs associated if they leaving the organization). Third, employees with normative commitment, they will be obligated to stay with the organization. Given that one argued that organizational commitment is an attitude about an employee's loyalty to organization and is an ongoing process through which employees express their concern for the organization as well as its continued success and well-being.

Job Performance

Job performance can be regarded as outcomes when a job is finished. It represents the levels of achievement of each job, [16] commented that it is the fulfillment of organizational regulations, expectations, or requirements for an official role. It can be measured by outcomes and it is the contribution to organizational goals [11]. Moreover, job performance is productivity that reflects the job quantity, quality and contribution. When productivity is high implies the overall performance will be high in the organization [17]. That is, job performance refers to the overall work outcomes, including efficacy, efficiency, and effectiveness [18] [19]. Korman, A. (1977) also pointed that job ability and skill, motivation, and role perception are three determinants to affect individual job performance [20]. Beyond that, [19] argued that the performance evaluation can be used to build incentives standards to make organizational members understand their contributions and the direction to their efforts. The evaluations of job performance are to (a) indicate the necessities of training and development, (b) assess the effects of employees' development and recruitment plan and enact incentive standards, (c) assist personnel decisions such as transfer, promotion, or layoff, and (d) provide feedback for employees in order for them to understand how performances are evaluated [3].

Employee performance is defined in different ways by scholars. Employee performance is a typical term in the field of human resources, and employee performance is regarded as the ability of employees to achieve organizational goals more effectively and efficiently. Organizations need individuals with high-performance to achieve their goals, provide their professional products and services, and achieve a competitive advantage. Employee performance is the task of successfully completing an individual or individual identity that measured by the supervisor or organization, with the predefined acceptable criteria, while making effective use of the available resources in a changing environment [21]. Robbins, (2001) pointed out that job performance described a function of the interaction between employee competence and motivation [3].

Leadership Style, Organizational Commitment and Job Performance 
Nyengane, M. H. (2007) found that leadership style has no effect on the commitment of employees in their study on 197 professionals in university libraries in Punjab and Islamabad [22]. Noordin \& Jusoff, (2009) in their study on 200 respondents constructs among University academic staff at a selected South African institution and the result revealed a weak but statistically significant relationship between transactional leadership and normative commitment [1]. Lee, (2009) found out that transformational leadership correlates significantly with organizational commitment with samples of research and development professional in Singapore [23]. May et. al (2009) in their study on 156 respondents in the Malaysia context revealed that three dimensions of transformational leadership namely, intellectual stimulation, idealized influence and inspirational motivation were significantly predicting affective commitment and normative commitment respectively [24].

Chun-Hong et.al. (2002) found manager and employee relationships fostered cooperative activities and positively related to productivity [25]. Positive relationships between managers and employees enhance leaders' ability to direct activities and create a productive workplace [26]. Leaders will influence organizational commitment and job performance because they can lead employees toward the achievement of job objectives. Leaders can guide individuals or groups to finish the goals and develop organizational commitment within employees [27] [28]. Leadership style has a positive influence on job performance [23] [29].
Jack et. al. (2012) in their research the samples were 127 employees at Municipal Waterworks of Jayapura, Papua Indonesia and revealed that organizational commitment significantly influence to employee performance directly or indirectly through work satisfaction [30]. Empirical investigation about organizational commitment with the employee performance have been done by [31] and the results showed that the organizational commitment impact positively to the performance. While research of [32] the results showed negative correlation between organizational commitment and the work performance.

\section{Research Method}

Research Framework

The purpose of this study is to identify the factors that impact on job performance among the academicians in Chinese higher education field. The researcher developed the conceptual framework and figured out the instrument scales for each variable to measure the academicians' job performance towards the private higher education institutions. In this proposed model, leadership style as independent variable, job performance as dependent variable, organizational commitment is mediating variable. This study attempts to demonstrate the mediating effect of organizational commitment between leadership style and job performance (See Figure 1).

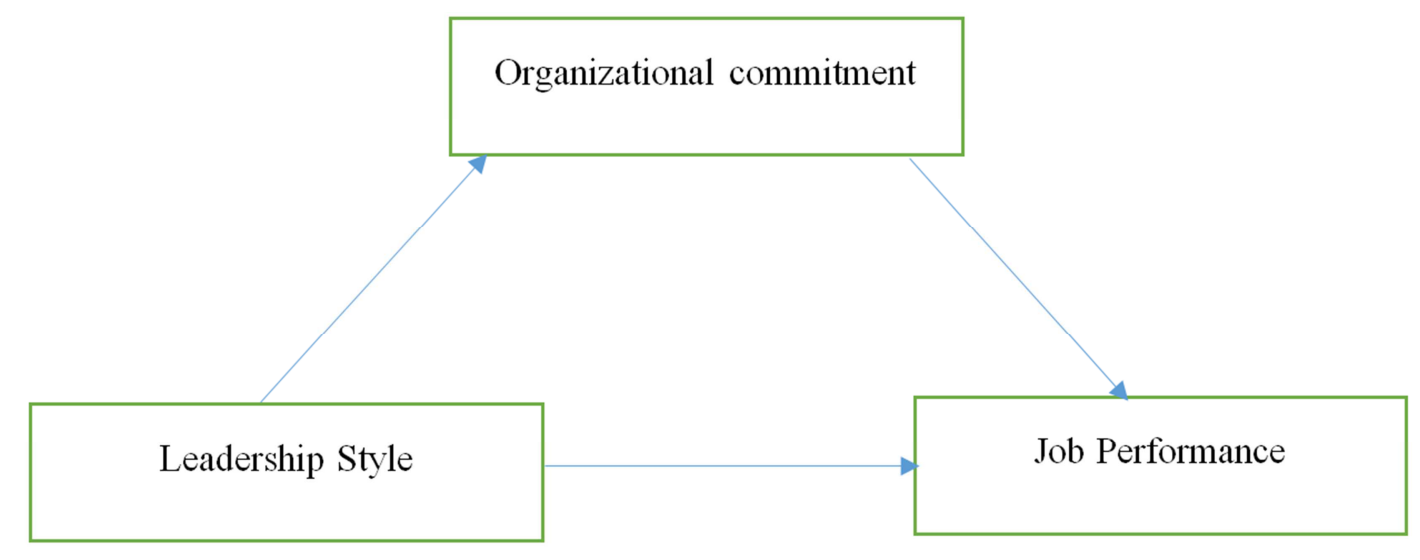

Figure 1. Conceptual Framework.

Research Hypotheses

The study proposed that research hypotheses as follows:

H1: There is a positive relationship between leadership style and organizational commitment.

H2: There is a positive relationship between leadership style and job performance.

H3: There is a positive relationship between organizational commitment and job performance.

H4: Organizational commitment will mediate the relationship between leadership style and job performance.

Research Design and Sample

The questionnaire was measured by three measurement dimensions, including leadership style, organizational commitment, job performance with a 5-point Likert scale questions $(1=$ strongly disagree to $5=$ strongly agree $)$. All measurement was measured by the previously developed instrument. Leadership style scale was adopted from [27] with 7 items and Job performance has utilized [33] job performance scale with 7 items and organizational commitment was adopted from [15] TCM Employee Commitment Survey (TCMECS) with 7 items. The reliability for these instruments comprised of 0.95 for leadership style, 0.72 for job performance, and 0.83 for organizational commitment, which surpassed the threshold value Cronbach' s alpha of 0.7 as suggested by [34]. Pre-test was conducted among 30 academicians in order to determine the reliability of the measurement. Convenience sampling was adopted in this study to collect data from academicians in the top ten 
Chinese private universities and Smart PLS to perform data analysis. 800 questionnaires were dispatched in total, and 470 copies were ready for analysis. The effective response rate is $58 \%$.

\section{Results}

\subsection{Construct Validity and Reliability}

Table 1. Construct Reliability \& Validity.

\begin{tabular}{lllllll}
\hline & AVE & AVE Sqrt & CR & R Square & CA & Comm \\
\hline LS & 0.517 & 0.719 & 0.882 & 0.000 & 0.844 & 0.517 \\
OC & 0.554 & 0.744 & 0.896 & 0.471 & 0.865 & 0.554 \\
JP & 0.590 & 0.768 & 0.910 & 0.438 & 0.884 & 0.590 \\
\hline
\end{tabular}

Composite reliability is similar with Cronbach's alpha, which used to measure construct reliability and the acceptable values should be greater than 0.6 [35]. The frequently applied measurement to assess convergent validity is the average variance extracted (AVE) and the value of AVE should be above 0.5 which is considered as adequate [36] [3]. The constructs achieved a higher Cronbachs Alpha than recommended 0.7 as well [37]. According to the criteria of each value, it displayed that all the constructs greater than the minimum required for each parameter [38].

Table 2. Variable Correlation Matrix based on AVE Square Root.

\begin{tabular}{llll}
\hline & LS & OC & JP \\
\hline LS & $\mathbf{0 . 7 1 9}$ & & \\
OC & 0.6371 & 0.744 & \\
JP & 0.6491 & 0.5753 & 0.768 \\
\hline
\end{tabular}

Table 2 shows the constructs correlation coefficient among the variables. It found that the correlation of the two constructs is lower that the square root of AVE which indicates that the data met the Discriminant Validity [39].

\subsection{Model Analysis}

The Figure 2 displays the direct paths which include leadership style to organizational commitment and leadership style to job performance. The path coefficients are 0.637 and 0.649 respectively and were significant at the 0.000 level. Thus, there is no indirect effect needs hypothesize or evaluate.

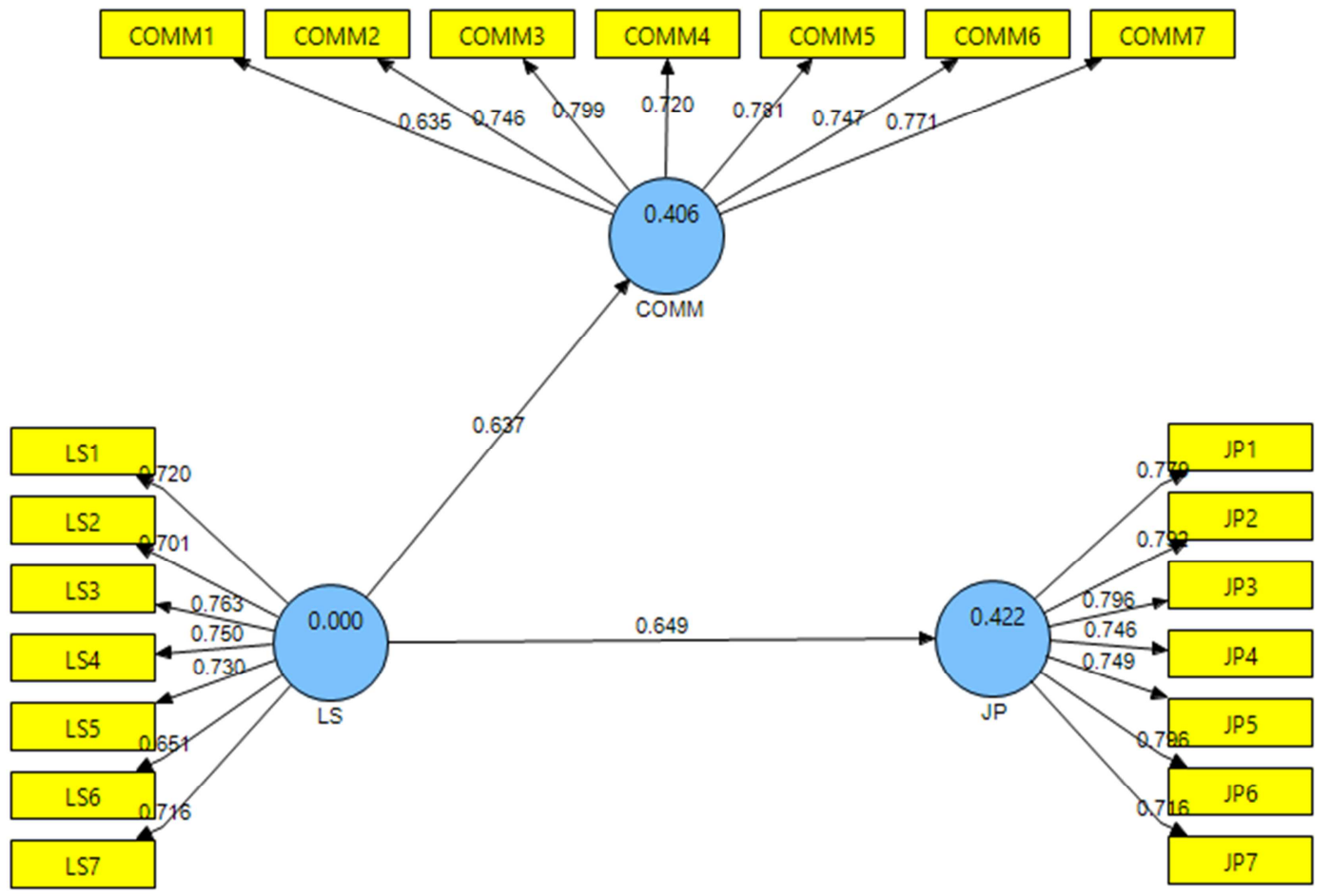

Figure 2. Direct Path Coefficient and $R^{2}$.

Table 3. Direct Model Path Coefficient.

\begin{tabular}{ll}
\hline & Path \\
\hline LS-->OC & 0.637 \\
LS-->JP & 0.649 \\
\hline
\end{tabular}

Table 4. Indirect Model Path Coefficient.

\begin{tabular}{ll}
\hline & Path \\
\hline LS-->OC & 0.638 \\
OC-->JP & 0.278 \\
LS-->JP & 0.473 \\
\hline
\end{tabular}

Next step, the indirect relationship model was presented in figure 3 with organizational commitment plays a mediating role between leadership style and job performance. The two distinct models were obtained based on [27] four-step technique to assess the mediating effect. The two models had:

1) A direct path from leadership style to organizational commitment

2) A direct path from leadership style to job performance

3) A direct path from organizational commitment to job 
performance

4) An indirect path from leadership style to organizational commitment and then from organizational commitment to job performance.

Mediating effect was built when the indirect path through the mediator leads to the direct path coefficient between the independent variable and dependent variable decreases in the model. The direct path means without intervention of mediator through the path. The direct path standardized beta was 0.649 and turn into 0.473 after intervened by organizational commitment as a mediator (Table 4). The number was decreased between the relationship of leadership style to job performance accounted by the mediator was 0.176 which represent $27.12 \%$ of the direct effect.

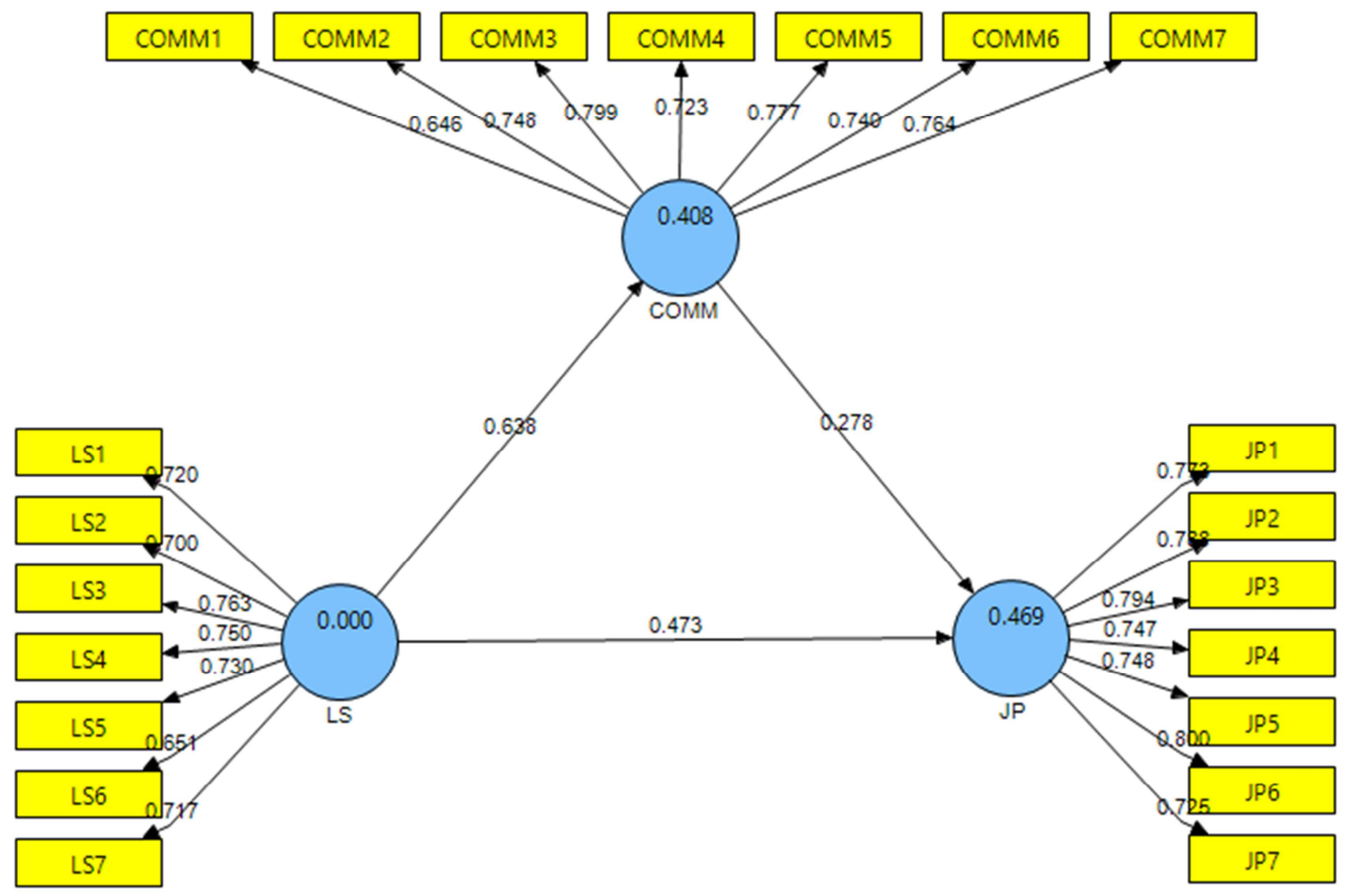

Figure 3. Indirect Path Coefficient and R2.

The significance of mediation effect was measured by the application of Process mentioned by [4], which is bootstrapping technique. The result extracted from Process exhibits that the indirect effect of leadership style to job performance with the present of organizational commitment as a mediating factor is insignificant where the lower level confidence level (LLCL) is 0.0329 and upper level confidence level (ULCL) is 0.0592 (Table 5). The indirect effect is significant because zero is not within this interval, which means the indirect effect of leadership style on job performance was set up. Therefore, the indirect path leadership style to job performance through organizational commitment as mediation is significant and this model is established.

Table 5. Indirect Effect Service Quality on Trust.

\begin{tabular}{lllll}
\hline Indirect & Effect & Boot OC & Boot LLCI & Boot ULCI \\
\hline OC & 0.0118 & 0.0237 & 0.0329 & 0.0592 \\
\hline
\end{tabular}

Table 6. Hypotheses Result.

\begin{tabular}{llll}
\hline Hypothesizes Relationship & Path Coefficient & p-value & Conclusion \\
\hline$H 1$ & There is a positive relationship between leadership style and organizational commitment & 0.637 & 0.00 \\
$H 2$ & There is a positive relationship between leadership style and job performance & 0.649 & Supported \\
$H 3$ & There is a positive relationship between organizational commitment and job performance & 0.278 & Supported \\
H4 & There is a positive indirect relationship between leadership style, organizational commitment and & 0.00 & 0.473 \\
& job performance & Supported & \multirow{2}{*}{ Supported } \\
\hline
\end{tabular}

\section{Conclusion and Discussion}

This study intends to establish an understanding of the mediating effect of organizational commitment on leadership style and job performance relationship in Chinese private universities. It also developed probable causal relationship among the variables which are leadership style, organizational commitment and job performance. The results displayed that leadership style has a positive and significant direct effect on organizational commitment [40], and it was found that leadership style has a positive and significant direct effect on job performance in the same model it consistent with previous studies [41] [42]. Organizational 
commitment has significant and positive relationship with job performance in line with previous studies [43] [44]. Further, the mediating effect of organizational commitment was introduced as a mediator in leadership style and job performance relationship was also established and it was significance, with the link of past studies, organizational commitment has positive and significant mediating effect on the leadership style and job performance [44] [45]. Yet, this study researched on the private higher education sector in China. Main limitation of this study was geographical limitation. There are long distance of each province of China, so that the researcher mainly applied the method of online data collection, as well as gained the academicians' email address from the official private universities' websites. It contributes practically to create an applicable view of leadership, commitment and job performance for managers of the targeted population in order to equip them with a new set of workable knowledge for making more effective decisions and setting policies more efficiently.

\section{References}

[1] Noordin \& Jusoff, (2009). Performance Indicators in Higher Education: Buckingham, in Chen et al. The development of an employee satisfaction model for higher education. TQM Mag. 18 (5): 484-500.

[2] Jing Lei, (2012). Levels of job satisfaction amongst Malaysian academic staff. Asian Social Science Journal, 5 (5) $122-126$.

[3] Robbins, (2001) Organizational Behavior. (9th ed.). New Jersey: Prentice Hall Inc.

[4] Ayes, A. F. (2012). Beyond Baron and Kenny: Statistical mediation analysis in the new millennium. Communi-cation Monographs, 76, 408-420.

[5] Barbuto, J. E., Fritz, S. M., \& Man, D. (2002). A field study examining two measures of work motivation for predicting leaders' influence tactics used. Journal of Social Psychology, I42 (5), 601-616.

[6] Bass, (1981). Stodgill's handbook of leadership: A survey of theory and research. New York: Free Press.

[7] Avolio, B., Luthans, F., \& Walumbwa, F. O., (2004). Authentic leadership: Theory-building for veritable sustained performance. Working paper. Gallup Leadership Institute, University of Nebraska, Lincoln.

[8] Muchinsky, P. M. (2003) Psychology Applied to Work. 7th Edition, Wadsworth, Belmont.

[9] Newstrom, J., \& Davis, K. (2007). Organizational Behavior: Human Behavior at Work. New Delhi: McGraw-Hill.

[10] Schmuck, P., \& Schultz, W. P. (2002, Eds.). Psychology of sustainable development. Boston: Kluwer Academic Publishers.

[11] Borman \& Motowidlo, (1993). Research Methodology for Business \& Social Science. University Publication Centre (UPENA), UiTM.
[12] Werner, A. (2007). Organisational behaviour: a contemporary South African perspective. Pretoria: Van Schaik Publishers.

[13] Mowday, R. T., Steers, R. M., \& Porter, L. W. 1979. The Measurement of Organizational Commitment. Journal of Vocational Behavior, 14 (2): 224-247.

[14] Garg, A. K, D. Ramjee, D. (2013). The Relationship between Leadership Styles and Employee Commitment at a Parastatal Company in South Africa. International Business \& Economics Research Journal, 12 (11) 1411-1436.

[15] Meyer J and Allen N (1997), "Commitment in the Workplace: Theory, Research, and Application", Sage Publications.

[16] Byars \& Rue, (2000). Relationship between Organizational Culture, Leadership Behavior and Job Satisfaction.

[17] Su, (1999); Schermerhorn, (2000). Sun, (2001). The Influence of a Pay Increase on Job.

[18] Tsao, Huang, Huang, Chang, \& Wang, (1997). Naunyn Schmiedebergs Arch Pharmacol. 1997 May; 355 (5):551-8.

[19] Hsu, (2005) Structural basis for origin recognition complex 1 protein-silence information regulator 1 protein interaction in epigenetic silencing. Proc Natl Acad Sci U S A 102 (24): 8519-24.

[20] Korman, A. (1977). Organization Behavior. Englewood Cliffs, NJ: Prentice Hall.

[21] Mathis \& Jackson, (2009). Manajemen Sumber Daya Manusia. Edisi Sepuluh. Jakarta: Salemba Empat.

[22] Nyengane, M. H. (2007). The relationship between leadership style and employee commitment: an exploratory study in an electricity utility of South Africa. (Unpublished Masters of Business Administration, Rhodes University, South Africa.

[23] Lee, (2009). Training, Wages, and Sample Selection: Estimating Sharp Bounds on Treatment Effects, Review of Economic Studies 76: 1071-1102.

[24] May Chiun Lo, Thurasamy Ramayah, Jerome Kueh Swee Hui, (2009), 12 (1) Journal of Business and Management.

[25] Chun-Hong, Yu, and Tjosvold (2002), Leadership \& Organization Development Journal 23/3, pp134-144.

[26] Humphreys \& Einstein, (2004). Leadership and temperament congruence: Extending the expectancy model of work motivation. Journal of Leadership and Organizational Studies, 10 (4), 58-79.

[27] Baron, R. M., \& Kenny, D. A. (1986). The moderatormediator variable distinction in social psychological research: Conceptual, strategic and statistical considerations. Journal of Personality and Social Psychology, 51, 11731182.

[28] Marlowe, Jr., H A., Nyhan, R. C. (1992). Development and psychometric properties of the organizational trust inventory, unpublished manuscript, University of Florida.

[29] Pan, (2006). Exploring Monitoring, Work Environment And Flexibility As Predictors Of Job Satisfaction Within Australian Call Centres. International Journal of Business and Management. 6 (8), pp: 75-93. 
[30] Jack Henry Syauta, Eka Afnan Troena, Margono Setiawan (2012), The Influence of Organizational Culture, Organizational Commitment to JobSatisfaction and Employee Performance. International Journal of Business and Management Invention. ISSN (Online): 2319-8028.

[31] Rashid, A., D. Harris, P. A Hollington and R. A. Khattak. 2002. On-farm seed priming: a key technology for improving the livelihood of resource poor farmers on saline lands. Centre for Arid Zone Studies, University of Wales, UK.

[32] Darwish A. Yousef, (2000) "Organizational commitment: a mediator of the relationships of leadership behavior with job satisfaction and performance in a non-western country", Journal of Managerial Psychology, Vol. 15 Issue: 1, pp. 624.

[33] Goodman, S. A., \& Svyantek, D. J. (1999). Personorganization fit and contextual performance: Do shared values matter. Journal of Vocational Behavior, 55 (2), 254275.

[34] Nunnally, J. C. (1978). Psychometric theory (2 ${ }^{\text {nd }}$ ed.). New York: McGraw-Hill.

[35] Bagozzi and Yi, (1988). Perilaku Keorganisasian. Edisi Kedua. Yogyakarta: Graha Ilmu.

[36] Homburg and Giering, (1996). Do satisfied customers really pay more? A study of the relationship between customer satisfaction and willingness to pay. Journal of Marketing, 69 (2), 84-96.

[37] Hair et al, (2005). Management. Upper Saddle River, NJ: Prentice Hall.
[38] Chin, (1998). "The Partial Least Squares Approach for Structural Equation Modeling." In GA Marcoulides (ed.), Modern Methods for Business Research, pp. 295-336. Lawrence Erlbaum Associates, London.

[39] Geffen \& Staub, (2000) "Structural equation modeling and regression: guidelines for research practice", Communications of the Association for Information Systems, Vol. 4 No. 7, pp. 1-77.

[40] Lee, (2010). Mert et al, 2010 Market orientation, service quality and organizational performance in service organizations in Malaysia. Asia-Pacific Journal of Business Administration, 3, 8-27.

[41] Deluga \& Souza, (2011). The moderating effect of gender in the adoption of mobile banking. International Journal of Bank Marketing, 28, 328-341.

[42] Thamrin, (2012). SERVQUAL in Malaysian universities: Perspectives of international students. Business Process Management Journal, 17, 67-81.

[43] Meyer et al., (2002). Services' marketing: Integrating customer focus across the firm (International edition). Boston, MA: McGraw-Hill.

[44] Chiet al., (2007) Using PLS path modeling for assessing hierarchical construct models: Guidelines and empirical illustration. MIS Quarterly, 33, 177-195.

[45] Yeh \& Hong, (2012). Market orientation, competitive advantage, and performance: A demand-based perspective. Journal of Business Research, 62, 1063-1070. 